\title{
Árangur míturlokuviðgerða á Íslandi 2001-2012
}

\author{
Jóhanna Fríða Guðmundsdóttir læknir, Sigurður Ragnarsson³ læknir, Arnar Geirsson læknir, Ragnar Danielsen² læknir, \\ Tómas Guðbjartsson ${ }^{1,4}$ læknir
}

\section{ÁGRIP}

Inngangur: Tilgangur bessarar rannsóknar var að kanna árangur míturlokuviðgerða á Íslandi, en pað hefur ekki verið gert áður. Efniviður og aðferðir: Afturskyggn rannsókn á 125 sjúklingum (meðalaldur 64 ár, bil: 28-84 ár, 74\% karlar) sem gengust undir míturlokuviðgerð vegna míturlokuleka á Landspítala 2001-2012. Ábending fyrir aðgerð var míturlokuhrörnun hjá 70 (56\%) sjúklingum, en starfrænn leki hjá 55 (44\%). Heildarlifun var reiknuð með aðferð Kaplan-Meier en miðgildi eftirfylgdar var 3,9 ár (bil: 0-11,7 ár).

Niðurstöður: Aðgerðum fjölgaði á rannsóknartímabilinu úr 39 i 86 á fyrra og síðara hluta pess. Meðal EuroSCORE var 12,9; tveir priðju sjúklinga voru í NYHA flokki III/IV fyrir aðgerð og 50\% með alvarlegan míturlokuleka. Tíundi hver sjúklingur hafði áđur farið í opna hjartaaðgerð og 12\% höfðu nýlegt hjartadrep. Allir sjúklingar, að premur undanskildum, fengu míturlokuhring (meðalstærð 28,4 mm). Framkvæmt var brottnám á hluta lokublaðs hjá 51 sjúklingi (41\%), 28 fengu ný lokustög úr gerviefni $\left(\right.$ Goretex ${ }^{\circledR}$ ) og 7 Alfieri-saum. Hjá $83 \%$ sjúklinga var einnig framkvæmd önnur hjartaaðgerð, oftast kransæðahjáveita (53\%), Maze-aðgerð (31\%) eða ósæðarlokuskipti (19\%). Meiriháttar fylgikvillar greindust hjá rúmum helmingi sjúklinga, algengastir voru hjartadrep, enduraðgerð vegna blæðingar og hjarta- og öndunarbilun. Minniháttar fylgikvillar greindust í $71 \%$ tilfella. Átta sjúklingar létust innan 30 daga frá aðgerð (6\%), en 5-ára lifun var $79 \%$; $84 \%$ hjá sjúklingum með míturlokuhrörnun og $74 \%$ hjá peim með starfrænan leka.

Ályktun: Míturlokuaðgerðum hefur fjölgað umtalsvert á síðasta áratug á Íslandi. Fylgikvillar eru tíðir en dánartíðni <30 daga og langtímalifun er svipuơ og í sambærilegum erlendum rannsóknum.
'Hjarta- og lungnaskurðdeild, ${ }^{2}$ hjartadeild, Landspítala, ${ }^{3}$ hjartaskurðdeild Háskólasjúkrahússins á Skáni í Lundi, Svíbjóð, ${ }^{4}$ ææknadeild $\mathrm{HI}$ Tómas Guðbjartsson tomasgud@landspitali.is

Greinin barst 20. mars 2014, sambykkt til birtingar 5. september 2014. gefin upp.

\section{Inngangur}

Á Vesturlöndum er leki í míturloku algeng ábending fyrir opinni hjartaskurðaðgerð, en kransæðahjáveita og ósæðarlokuskipti eru pó mun algengari hjartaaðgerðir. ${ }^{1}$ Orsakir míturlokuleka eru aðallega tvenns konar: hrörnunarsjúkdómur í lokunni (degenerative) eða starfrænn leki (functional). ${ }^{2}$ Við hrörnunarsjúkdóm verður bakfall (mitral valve prolapse) á öðru eða báðum lokublöðunum sem veldur leka. Pessu valda hrörnunarbreytingar í lokublöðunum sjálfum eða slit eða lenging á lokustögum (chordae tendinae). ${ }^{3}$ Við starfrænan leka eru lokublöð og lokustög hins vegar eðlileg, en blóðpurrð í vinstri slegli og totuvöðvum getur truflað hreyfingu lokublaðanna, aðallega pó aftara míturlokublaðsins. ${ }^{3}$ Einnig getur víkkun á vinstri slegli, til dæmis vegna útbreidds blóðpurrðar- eða hjartavöðvasjúkdóms, valdið víkkun á míturlokuhringnum. Lokublöðin ná pá ekki að mætast sem veldur leka í miðri lokunni. ${ }^{3}$ Aðrar sjaldgæfari orsakir míturlokuleka eru kalkanir í míturlokuhringnum, hjartapelsbólga, gigtsótt og bráður míturlokuleki vegna rofs á totuvöðva i kjölfar hjartadreps (papillary muscle rupture). ${ }^{1}$

Míturlokuleki er greindur með hjartaómskoðun, annaðhvort um brjóstvegg eða vélinda. ${ }^{4,5}$ Umfang og orsök lekans er metið og áhrif hans á stærð, samdráttargetu og starfsemi vinstri slegils. ${ }^{6}$ Auk pess er mæld stærð og rúmmál vinstri gáttar, stærð og sam- dráttargeta hægri slegils og lagt mat á slagæðaprýsting í lungnablóðrás. ${ }^{6}$

Vægur míturlokuleki er oftast meðhöndlaður með lyfjum, sérstaklega starfrænn leki, en við alvarlegan leka parf yfirleitt að beita skurðaðgerð, enda pótt viðgerðir með hjartapræðingartækni séu nú í örri próun. ${ }^{7}$ Á síðustu tveimur áratugum hafa míturlokuviðgerðir rutt sér til rúms í stað lokuskipta, sérstaklega við hrörnunarsjúkdómi í lokunni. ${ }^{8}$ Lokublöðin eru pá lagfærð og komið fyrir míturlokuhring til að styrkja viðgerðina. ${ }^{9}$ Viðgerð á starfrænum leka felast hins vegar í pví að prengja míturlokuopið með stífum hring. ${ }^{10}$ Fjölmargar rannsóknir hafa sýnt að snemmkominn árangur og langtímalifun eru umtalsvert betri eftir viðgerð en lokuskipti. ${ }^{2,11}$ Auk pess er kostur að ekki er pörf á langtíma blóðpynningarmeðferð eftir viðgerð og starfsemi vinstri slegilsins er betur varðveitt. ${ }^{11}{ }^{12}$ Á stærri sjúkrahúsum erlendis er árangur míturlokuviðgerða víða mjög góður og dánarhlutfall innan 30 daga undir $2 \%$ við hrörnunarsjúkdómi og 5-10\% hjá sjúklingum með starfrænan leka. ${ }^{13}$

Áður hefur birst rannsókn á árangri míturlokuskipta á Íslandi ${ }^{14}$ en upplýsingar um árangur míturlokuviðgerða hefur vantað hérlendis. Markmið pessarar rannsóknar var að kanna árangur míturlokuviðgerða á Landspítala á 12 ára tímabili með áherslu á snemmkomna fylgikvilla og dánarhlutfall innan 30 daga. 


\section{Efniviður og aðferðir}

Rannsóknin var afturskyggn og náði til sjúklinga sem gengust undir míturlokuviðgerð á Landspítala á tímabilinu 1. janúar 2001 til 31. desember 2012. Listi yfir sjúklingana var fenginn úr sjúklingabókhaldi Landspítala en einnig var leitað í aðgerðaskrá hjarta- og lungnaskurðdeildar spítalans.

Alls gengust 152 einstaklingar undir míturlokuviðgerð á pessu 12 ára tímabili. Teknir voru með bæði sjúklingar með hrörnunarsjúkdóm í lokunni (H-hópur) og starfrænan lokuleka (S-hópur). Gefnar eru upp niðurstöður fyrir alla sjúklingana saman en jafnframt hvorn hópinn fyrir sig, enda um töluvert ólíka sjúklingahópa аð ræða. Alls var 27 einstaklingum sleppt, meðal annars peim sem höfðu sýkingu í míturloku (n=8) eða brátt hjartadrep (n=5). Einnig var tveimur sjúklingum sem áður höfðu gengist undir viðgerð á míturlokunni sleppt. Rannsóknarpýðið taldi pví 125 einstaklinga.

Klínískar upplýsingar fengust úr sjúkraskrám og voru skráðar samtals 118 breytur, par á meðal aldur, kyn, áhættupættir hjartaog æðasjúkdóma og saga um kransæðasjúkdóm, langvinna lungnateppu, nýrnabilun og fyrri hjartaaðgerðir. Einnig voru skráð einkenni fyrir aðgerð, sem meðal annars voru metin samkvæmt flokkun NYHA (New York Heart Association) á hjartabilun. Sjúklingarnir voru einnig metnir með tilliti til áhættu við svæfingu samkvæmt ASA-flokkunarkerfinu (American Association of Anesthesiology). Нæð og pyngd var skráð samkvæmt svæfingarblöðum og út frá peim upplýsingum reiknaður líkamspyngdarstuðull. Einnig var reiknað út fyrir alla sjúklinga bæði lógístískt EuroSCORE ${ }^{15}$ (European System for Cardiac Operative Risk Evaluation) og EuroSCORE $\mathrm{II}_{1}^{16}$ sem eru áhættulíkön til að meta dánarlíkur innan 30 daga frá aðgerð.

Skráðar voru niðurstöður úr hjartaómskoðunum sem gerðar voru fyrir aðgerð og um pað bil viku eftir aðgerð. Orsök míturlokulekans og ábending fyrir míturlokuviðgerð var metin út frá hefðbundinni hjartaómun. ${ }^{17}$ Úr ómsvörum fyrir aðgerð var meðal annars skráð stærð vinstri slegils í hlé- og slagbili, útstreymisbrot vinstri slegils (ejection fraction, EF), veggpykkt og stærð vinstri gáttar. Vinstri slegill var metinn stækkaður pegar innra pvermál hans var $\geq 45 \mathrm{~mm}$. Útstreymisbrot vinstri slegils var talið skert pegar pað var $\leq 60 \%$. ${ }^{6}$ Leki í lokunni var metinn á skalanum frá einum (vægur leki) og upp í prjá (mikill leki) samkvæmt viðurkenndum klínískum leiðbeiningum. ${ }^{6}$ Alvarlegur lungnaslagæðaháprýstingur var skilgreindur sem slagbilsprýstingur í hægri slegli yfir $60 \mathrm{mmHg}{ }^{15}$ Í sumum tilfellum var gerð hjartaómun frá vélinda til nánara mats á orsök og magni lekans. Útbreiðsla kransæðasjúkdóms var skráð samkvæmt niðurstöðum úr hjartapræðingu.

Af aðgerðartengdum breytum var kannað hvort um val- eða bráðaaðgerð var að ræða og hvort aðrar hjartaaðgerðir hefðu verið framkvæmdar samtímis lokuviðgerðinni. Skráður var fjöldi kransæðatenginga ef gerð var hjáveituaðgerð samtímis, tími á hjarta- og lungnavél, tangar- (aortic cross clamp time) og aðgerðartími. Einnig var skráð hvers konar viðgerð var framkvæmd, blæðing í brjóstholskera fyrstu 24 klukkustundir eftir aðgerð, tími á öndunarvél í klukkustundum og magn blóðhlutagjafa í einingum.

Skráðir voru fylgikvillar eftir aðgerð fram að útskrift af sjúkrahúsi, eða fram að andláti ef sjúklingur lést fyrir útskrift. Fylgikvillarnir voru flokkaðir í alvarlega og minniháttar. Til alvarlegra fylgikvilla töldust enduraðgerð vegna blæðingar, aðrar enduraðgerðir á hjarta, djúp sýking í bringubeinsskurði, bráður nýrnaskaði sem
Tafla I. Sjúklingatengdir pættir hjá 125 sjúklingum sem gengust undir míturlokuviðgerð á Íslandi 2001-2012. Gefinn er upp fjöldi sjúklinga (\%) nema meðaltöl með staðalfrávikum fyrir aldur og EuroSCORE.

\begin{tabular}{|c|c|c|c|}
\hline & $\begin{array}{c}\text { Allir } \\
(n=125)\end{array}$ & $\begin{array}{c}\text { Starfrænn } \\
\text { lokuleki } \\
(n=55)\end{array}$ & $\begin{array}{l}\text { Hrörnunar- } \\
\text { lokusjúkdómur } \\
(\mathrm{n}=70)\end{array}$ \\
\hline Karlar & $92(74)$ & $42(76)$ & $50(71)$ \\
\hline Aldur (ár) & $64 \pm 14$ & $70 \pm 9$ & $60 \pm 15$ \\
\hline Áður farið í hjartaaðgerð & $12(10)$ & $8(15)$ & $4(6)$ \\
\hline Háprýstingur & $85(68)$ & $43(78)$ & $42(60)$ \\
\hline Sykursýki & $6(5)$ & $4(7)$ & $2(3)$ \\
\hline Saga um reykingar & $69(55)$ & $30(55)$ & $38(54)$ \\
\hline Líkamspyngdarstuðull $\geq 25$ kg/m² & $81(65)$ & $36(66)$ & $45(64)$ \\
\hline Langvinn lungnateppa & $19(15)$ & $10(18)$ & $9(13)$ \\
\hline $\begin{array}{l}\text { Lungnaháprýstingur } \\
\text { (slagbilsprýstingur >60 mmHg) }\end{array}$ & $50(40)$ & $24(34)$ & $26(47)$ \\
\hline Kransæðasjúkdómur & $68(54)$ & $44(80)$ & $24(34)$ \\
\hline \multicolumn{4}{|l|}{ NYHA flokkur } \\
\hline$I+\|$ & $44(35)$ & $9(16)$ & $35(50)$ \\
\hline III + IV & $81(65)$ & $46(84)$ & $35(50)$ \\
\hline \multicolumn{4}{|l|}{ ASA* flokkur $^{*}$} \\
\hline $1+2$ & $17(14)$ & $1(2)$ & $16(23)$ \\
\hline 3 & $82(66)$ & $37(67)$ & $45(64)$ \\
\hline 4 & $26(21)$ & $17(30)$ & $9(13)$ \\
\hline EuroSCORE II & $5 \pm 7$ & $7 \pm 8$ & $3 \pm 4$ \\
\hline LogEuroSCORE & $13 \pm 16$ & $19 \pm 20$ & $8 \pm 10$ \\
\hline
\end{tabular}

*American Association of Anesthesiology, Ameríska svæfingalæknafélagið.

parfnaðist blóðskilunar og öndunarbilun par sem purfti meðferð í öndunarvél (oft vegna andnauðarheilkennis, ARDS) eða barkaraufun. Heilaáfall (stroke) taldist einnig til alvarlegra fylgikvilla, sem og hjartadrep, fjöllíffærabilun og hjartabilun par sem pörf var á ósæðar- (intraaortic balloon pump, IABP) eða ECMO-dælu. Hjartadrep var skilgreint sem hækkun á hjartaensíminu CK-MB yfir 70 $\mu \mathrm{g} / \mathrm{L}$ eftir aðgerð en yfir $100 \mu \mathrm{g} / \mathrm{L}$ hjá peim sem einnig gengust undir Maze- eða brennsluaðgerð vegna gáttatifs. Við útreikninga á tíðni hjartadreps í eða eftir aðgerð var sleppt einstaklingum sem höfðu nýlegt hjartadrep fyrir aðgerð. ${ }^{15}$ Til minniháttar fylgikvilla töldust hjartsláttartruflanir, yfirborðssýking í skurðsári, pvagfærasýking, lungnabólga, aftöppun á fleiðruvökva og afturkræf blóðpurrð í heila (transient ischemic attack, TIA). Væg hjartabilun var einnig talin til minniháttar fylgikvilla og skilgreind sem pörf á samdráttarhvetjandi lyfjum í meira en sólarhring eftir aðgerð. Legutími var skráður í dögum, bæði á gjörgæslu og legudeild. Athugað var hversu margir létust innan 30 daga frá aðgerð, sem er hefðbundin skilgreining á skurðdauða (operative mortality).

Upplýsingar voru skráðar í forritið Microsoft Excel ${ }^{\circledR}$ (Microsoft, Redmond WA) og var pað notað í lýsandi tölfræði en aðrir útreikningar gerðir í IBM SPSS ${ }^{\circledast}$ (IBM, Armonk, NY). Við samanburð hópa var stuðst við t-próf fyrir samfelldar breytur og Kí-kvaðrat eða Fisher Exact próf fyrir flokkabreytur. Aðferð Kaplan-Meier var notuð til að áætla heildarlifun (overall survival) og miðast útreikningar við 1. febrúar 2013. Dánardagur var skráður samkvæmt upplýsingum úr dánarmeinaskrá. Miðgildi eftirfylgdar var 3,9 ár (bil: 0-11,7 ár). 


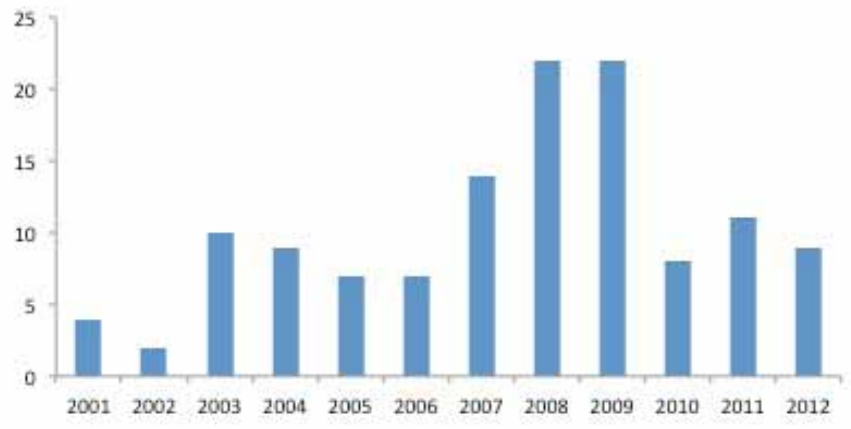

Mynd 1. Árlegur fjöldi míturlokuviðgerda á Íslandi frá 2001 til 2012.

Rannsóknin var framkvæmd með tilskildum leyfum frá Persónuvernd, Vísindasiðanefnd og framkvæmdastjóra lækninga á Landspítala.

\section{Niðurstöður}

Sjúklingar og fjöldi aðgerða

Af 125 sjúklingum voru 92 (74\%) karlar. Meðalaldur sjúklinga var $64 \pm 14$ ár og var sá yngsti 28 ára og elsti sjúklingurinn 84 ára (tafla I). Að meðaltali voru framkvæmdar 13 aðgerðir á ári ( bil: 2-22). Aðgerðum fjölgaði á rannsóknartímabilinu, eða úr 39 á fyrri hluta pess í 84 á síðari 6 árunum (mynd 1).

Tegund míturlokuleka, sjúklingatengdir pættir og einkenni

Allir sjúklingarnir höfðu að minnsta kosti meðal eða mikinn míturlokuleka. Starfrænan leka (S-hópur) höfðu 55 einstaklingar (44\%) og 70 (56\%) míturlokuhrörnun (H-hópur). Af pessum 70 sjúklingum voru 34 með slit á stögum lokublaðanna, 56 með bakfall á aftara lokublaði, 10 með bakfall á fremra blaði og 4 með bakfall á báðum lokublöðum.

Sjúklingatengdir pættir eru sýndir í töflu I, bæði fyrir sjúklinga í S- og H-hópi. Meðalaldur var 10 árum hærri í S-hópi $(\mathrm{p}<0,001)$, en kynjadreifing reyndist svipuð. Algengustu einkenni fyrir aðgerð voru mæði (86\%), hjartsláttarópægindi (54\%) og brjóstverkur (46\%). Sjúklingar í S-hópi voru með tvöfalt hærra EuroSCORE II og logEuroSCORE en peir sem voru í H-hópi og oftar í NYHA-flokki III eða IV fyrir aðgerð. Rúmlega helmingur (54\%) sjúklinganna hafði pekktan kransæðasjúkdóm og 15 peirra (12\%) höfðu fengið hjartadrep í aðdraganda innlagnar. Prír fjórðu (74\%) aðgerðanna voru valaðgerðir, en $25 \%$ peirra var gerður með flýtingu, oftast vegna hjartadreps fyrir aðgerð. Ein aðgerð var bráðaaðgerð vegna lokastigs hjartabilunar.

\section{Hjartaómun fyrir aðgerð}

Niðurstöður hjartaómskoðana fyrir aðgerð eru sýndar í töflu II. Í ómskoðunarvörum lágu fyrir upplýsingar um umfang míturlokuleka hjá öllum sjúklingum, útstreymisbrot hjá 123 (98\%), stærð vinstri gáttar hjá 92 (74\%) og stærð vinstri slegils í lok hlébils hjá 98 (78,\%) og í lok slagbils hjá 92 (74\%). Um helmingur sjúklinganna var með meðal míturlokuleka, en hinn helmingurinn mikinn leka. Mun fleiri höfðu mikinn leka í H-hópi (69\% á móti 26\%, p<0,001). Útstreymisbrot vinstri slegils var að meðaltali 54\% (bil: 20-80\%) og voru $51 \%$ sjúklinga metnir með skert útstreymisbrot $60 \%$ ).
Tafla II. Niðurstöður hjartaómskoðana fyrir aðgerð hjá sjúklingum sem gengust undir míturlokuviðgerðir á Íslandi 2001-2012. Gefin eru upp meðaltöl með staðalfráviki nema fyrir mikinn lokuleka, stækkaðan slegil i lok slagbils og skert útstreymisbrot eru gefin upp fjöldi og prósenta innan sviga.

\begin{tabular}{lccc}
\hline & $\begin{array}{c}\text { Allir } \\
(\mathrm{n}=125)\end{array}$ & $\begin{array}{c}\text { Starfrænn } \\
\text { lokuleki } \\
(\mathrm{n}=55)\end{array}$ & $\begin{array}{c}\text { Hrörnunar- } \\
\text { lokusjúkdómur } \\
(\mathrm{n}=70)\end{array}$ \\
\hline Útstreymisbrot vinstri slegils (\%) & $54 \pm 12$ & $49 \pm 13$ & $58 \pm 9$ \\
\hline Mikill lokuleki & $62(50)$ & $14(26)$ & $48(69)$ \\
\hline Stærð vinstri gáttar (mm) & $47 \pm 7$ & $47 \pm 7$ & $48 \pm 7$ \\
\hline Stærð vinstri slegils í lok hlébils (mm) & $60 \pm 9$ & $60 \pm 9$ & $60 \pm 9$ \\
\hline Stærð vinstri slegils í lok slagbils $(\mathrm{mm})$ & $41 \pm 10$ & $43 \pm 10$ & $40 \pm 9$ \\
\hline $\begin{array}{l}\text { Stækkaður slegill í lok slagbils } \\
\text { (LVESD } \geq 45 m m)\end{array}$ & $35(38)$ & $21(50)$ & $14(28)$ \\
\hline Skert útstreymisbrot (EF $\geq 60 \%)$ & $63(51)$ & $38(69)$ & $25(37)$ \\
\hline
\end{tabular}

Stærð vinstri slegils í lok slagbils var að meðaltali $41 \mathrm{~mm}$ og höfðu $38 \%$ stækkaðan vinstri slegil (LVESD $\geq 45 \mathrm{~mm}$ ). Ósæðarlokuleka höfðu 33 sjúklingar, en 17 höfðu að auki prengsli í ósæðarlokunni. Fimmtíu sjúklingar (40\%) höfðu marktækan lungnaslagæðaprýsting.

\section{Ábendingar og aðgerðartengdir pættir}

Míturlokuleki var helsta ábending fyrir aðgerð hjá 56 (45\%) sjúklingum; 49 (70\%) í H-hópi og hjá 7 (13\%) sjúklingum í S-hópi. Allir sjúklingarnir að premur undanskildum (98\%) fengu míturlokuhring (annuloplasty). Stærð ígrædds míturlokuhrings var að meðaltali $28 \pm 4 \mathrm{~mm}$ (bil: $23-33 \mathrm{~mm}$ ) og var stærðin nánast sú sama í H- og S-hópi. Að auki var hluti lokublaðs fjarlægður (resection) hjá 51 sjúklingi (41\%), lokustög úr gerviefni (pólýtetraflúroetýlen, Gore-tex ${ }^{\circledR}$ ) notuð hjá 28 (22\%) sjúklingum og Alfieri-saumur hjá 7 (6\%) einstaklingum.

Önnur hjartaaðgerð var framkvæmd samtímis hjá 104 sjúklingum (83\%), oftast kransæðahjáveita (53\%), Maze- eða brennsluaðgerð vegna gáttatifs (31\%) og ósæðarlokuskipti (19\%). Allir sjúklingarnir í S-hópi gengust undir aðra hjartaaðgerð samhliða en priðjungur sjúklinga í H-hópi gekkst einungis undir míturlokuviðgerð.

Aðgerðirnar tóku að meðaltali $303 \pm 117$ mínútur, par af voru $173 \pm 76$ mínútur á hjarta- og lungnavél, en meðaltangartími var $118 \pm 47$ mínútur. Aðgerðartími var 93 mínútum lengri að meðaltali hjá S- en H-hópi. Í 5 tilvikum varð meiriháttar blæðing ( $>5 \mathrm{~L})$ í aðgerð. Blæðing í brjóstholskera var að meðaltali $857 \pm 660 \mathrm{~mL}$ fyrstu 24 klukkustundirnar eftir aðgerð.

\section{Blóðhlutagjafir og legutími}

Gefnar voru að meðaltali 3,0 einingar af rauðkornapykkni eftir aðgerð (bil: 0-24), 5,0 einingar af blóðvökva (bil: 0-33) og 1,0 sett af blóðflögum (bil: 0-12). Í pessum útreikningum var einstaklingum sem blæddi meira en 5 L sleppt. Miðgildi tíma á öndunarvél eftir aðgerðina var 43 klukkustundir (bil: 4-450) og var hann tæplega 20 klukkustundum lengri hjá S- en H-hópi ( $>>0,001)$. Miðgildi gjörgæslulegu var 1,0 dagur (bil: 1-47) en heildarlegutími á sjúkrahúsi 13 dagar (bil: 0-81). Miðgildi legutíma var fjórum dögum lengri hjá S- en H-hópi. 
Tafla III. Snemmkomnir fylgikvillar hjá sjúklingum sem gengust undir míturlokuviðgerð á Íslandi 2001-2012. Sjúklingur getur haft fleiri en einn fylgikvilla. Fjöldi (\%).

\begin{tabular}{|c|c|c|c|}
\hline & $\begin{array}{c}\text { Allir } \\
(n=125)\end{array}$ & $\begin{array}{c}\text { Starfrænn } \\
\text { lokuleki } \\
(n=55)\end{array}$ & $\begin{array}{l}\text { Hrörnunar- } \\
\text { lokusjúkdómur } \\
(\mathrm{n}=70)\end{array}$ \\
\hline Alvarlegir fylgikvillar & $67(54)$ & $35(64)$ & $32(46)$ \\
\hline Hjartadrep tengt aðgerð* & $21(17)$ & $12(22)$ & $9(13)$ \\
\hline Alvarleg öndunarbilun (ARDS) & $3(2)$ & $3(6)$ & $0(0)$ \\
\hline Barkaraufun & $8(6)$ & $6(11)$ & $2(2)$ \\
\hline Enduraðgerð vegna blæðingar & $17(14)$ & $9(16)$ & $8(11)$ \\
\hline Pörf á ósæðardælu (IABP) & $18(14)$ & $11(20)$ & $7(10)$ \\
\hline $\begin{array}{l}\text { Bráð nýrnabilun sem leiddi til } \\
\text { blóðskilunar }\end{array}$ & $4(3)$ & $3(6)$ & $1(1)$ \\
\hline Heilablóðfall & $5(4)$ & $3(6)$ & $2(3)$ \\
\hline Djúp sýking í bringubeini & $5(4)$ & $5(9)$ & $0(0)$ \\
\hline Ígræddur gangráður & $6(5)$ & $3(6)$ & $3(4)$ \\
\hline Blóðsýking & $3(3)$ & $2(4)$ & $1(1)$ \\
\hline Minniháttar fylgikvillar & $87(70)$ & $43(78)$ & $44(63)$ \\
\hline Nýtilkomið gáttatif/-flökt ${ }^{\ddagger}$ & $29(23)$ & $15(27)$ & $14(20)$ \\
\hline Minniháttar hjartabilun ${ }^{\S}$ & $35(28)$ & $23(41)$ & $12(17)$ \\
\hline $\begin{array}{l}\text { Fleiðruvökvi sem krafðist } \\
\text { aftöppunar }\end{array}$ & $33(26)$ & $21(38)$ & $12(17)$ \\
\hline Lungnabólga & $20(16)$ & $14(26)$ & $6(9)$ \\
\hline Pvagfærasýking & $11(9)$ & $6(11)$ & $5(7)$ \\
\hline Yfirborðssýking í skurðsári & $7(6)$ & $5(9)$ & $2(3)$ \\
\hline Tímabundin blóðpurrð í heila & $2(2)$ & $1(2)$ & $1(1)$ \\
\hline Skurðdauð̃i ( $\leq 30$ dagar) & $8(6)$ & $4(7)$ & $4(6)$ \\
\hline
\end{tabular}

*CK-MB mæling yfir $70 \mu \mathrm{g} / \mathrm{L}$ (hjá sjúklingum sem ekki höfðu hjartadrep fyrir aðgerð) en yfir $100 \mu \mathrm{g} / \mathrm{L}$ hjá beim sem fóru i brennsluađgerð.

†Tekur aðeins til peirra 69 sjúklinga sem ekki höfðu pekkt gáttatif fyrir aðgerð.

§Samdráttarhvetjandi lyf í >24 klukkustundir.

\section{Fylgikvillar eftir aðgerð og 30 daga dánartíðni}

Fylgikvillar eftir aðgerð eru sýndir í töflu III. Alvarlegir fylgikvillar greindust hjá rúmlega helmingi sjúklinga (54\%). Algengastir voru hjartadrep í tengslum við aðgerð (17\%), enduraðgerð vegna blæðingar (14\%) og pörf á ósæðardælu vegna hjartabilunar (14\%). Í fjórum tilfellum (3\%) purfti nýrnaskilun vegna bráðs nýrnaskaða og 5 (4\%) sjúklingar hlutu heilaáfall í tengslum við aðgerð.

Minniháttar fylgikvillar greindust hjá 70\% sjúklinga. Algengastir voru væg hjartabilun (28\%), fleiðruvökvi sem parfnaðist aftöppunar $(26 \%)$, nýtilkomið gáttatif $(23 \%)$ og lungnabólga $(16 \%)$. Ekki reyndist munur á tíðni fylgikvilla á fyrra og síðari hluta rannsóknartímabilsins. Hjá 21 sjúklingi sem ekki gekkst undir aðra hjartaaðgerð en míturlokuviðgerð var tíðni alvarlegra fylgikvilla $29 \%$ og minniháttar fylgikvilla $24 \%$.

Dánartíðni innan 30 daga var 6\% og reyndist svipuð í S- og H-hópi. Hjá peim 8 sjúklingum sem létust innan 30 daga var algengasta dánarorsökin hjartadrep í tengslum við aðgerð, prír létust vegna blæðingar og einn vegna fjöllíffærabilunar. Pessir sjúklingar voru allir í NYHA-flokki III eða IV fyrir aðgerð. Helmingur peirra var með útfallsbrot $30 \%$ eða lægra og logEuroSCORE peirra var að meðaltali 41 (EuroSCORE II 17). Allir sjúklingarnir sem létust höfðu farið í aðra hjartaaðgerð samtímis míturlokuviðgerð.
Hjartaómskoðun eftir aðgerð og langtímaafdrif sjúklinga

Niðurstöður hjartaómskoðunar viku eftir aðgerð lágu fyrir hjá 108 sjúklingum (84\%). Alls voru 65\% sjúklinga án míturlokuleka (58\% í S- og 71\% í H-hópi), 25\% höfðu vægan leka (33\% í S- og 20\% í Hhópi) og 9\% sjúklinga voru með meðalmikinn leka (16 í S- og 5\% í H-hópi). Á Landspítala fundust ómskoðanir eftir meira en einn mánuð frá aðgerð (langtímaeftirfylgd) hjá einungis $40 \%$ sjúklinga. Pví var ekki unnið frekar úr peim gögnum.

Tveir sjúklingar purftu að gangast undir enduraðgerð tveimur og 30 mánuðum frá fyrstu míturlokuviðgerð. Í báðum pessum tilvikum var komið fyrir gerviloku (mechanical prosthesis). Langflestir sjúklinganna (98\%) purftu pví ekki enduraðgerð fyrstu 5 árin eftir míturlokuviðgerðina. Fimm ára heildarlifun var 79\%; 84\% í H-hópi og 74\% í S-hópi.

\section{Umræða}

Helstu markmið pessarar rannsóknar voru að meta árangur míturlokuviðgerða á Íslandi með áherslu á snemmkomna fylgikvilla og 30 daga dánarhlutfall. Míturlokuviðgerðum fjölgaði verulega á rannsóknartímabilinu. Eins og kemur fram í nýlegri rannsókn í Læknablaðinu hefur míturlokuskiptum fækkað verulega hér á landi og eru aðeins gerðar 2-4 slíkar slíkar aðgerðir á ári ${ }^{14}$. Svipuð próun hefur orðið erlendis, ekki síst í Bandaríkjunum par sem hlutfall míturlokuviðgerða við hrörnunarsjúkdómi hækkaði úr 51\% 1́ 69\% á tímabilinu 2000-2007.17 Mikill munur er pó á hlutfalli viðgerða milli bandarískra sjúkrahúsa en á stærri hjartaskurðdeildum sem sérhæfa sig í lokusjúkdómum er hlutfall viðgerða við míturlokuleka yfir $90 \% .{ }^{9}$ Pannig verður $80 \%$ viðgerðarhlutfall hér á landi, eins og kemur fram í grein okkar um míturlokuskipti í Læknablaðinu, að teljast mjög ásættanlegt. ${ }^{13}$

Míturlokuleki getur verið án einkenna svo árum skiptir en að lokum veldur aukið álag á vinstri slegil pví að hann stækkar og penst út. Slagrúmmál slegilsins eykst sem bætir dæluvirkni hjartans. Smám saman gefur slegillinn eftir og í kjölfarið fylgir vinstri hjartabilun með mæði og prekleysi. Lekinn í míturlokunni eykur einnig rúmmál vinstri gáttar sem stækkar.² Par sem mótstaða (afterload) vinstri slegils minnkar, getur útstreymisbrot slegilsins haldist „eðlilegt" prátt fyrir skerta samdráttargetu. Pví benda útstreymisbrot undir $60 \%$ og pvermál slegils í lok slagbils yfir $45 \mathrm{~mm}$ til skertrar samdráttargetu. Í núverandi rannsókn kemur fram að sjúklingar sem fóru í míturlokuviðgerð höfðu flestir mikil einkenni og voru 65\% sjúklinganna í NYHA-flokki III eða IV. Lungnaháprýstingur var mjög algengur fyrir aðgerð en sérstaklega hjá hópnum með starfrænan leka par sem hlutfallið var tæpur helmingur. Petta endurspeglast í háu logEuroSCORE, sem var 13\%, en til samanburðar var pað einnig hátt hjá peim sem gengust undir míturlokuskipti hér á landi, eða $15 \% .{ }^{14}$

Sjúklingar með míturlokubakfall vegna hrörnunarsjúkdóms voru flestir miðaldra karlmenn sem er í samræmi við erlendar rannsóknir.11,17 Hjá pessum sjúklingum er yfirleitt mælt með skurðaðgerð pegar um alvarlegan leka er að ræða. Pá eru einkenni hjartabilunar oftast til staðar og ómskoðun sýnir merki um álag og stækkun á vinstri slegli. ${ }^{6}$ Míturlokuviðgerð hjá pessum sjúklingum felst í pví að lagfæra lokublöðin; annaðhvort fjarlægja hluta peirra eða koma fyrir nýjum lokustögum úr polýtetraflúróetýleni $\left(\right.$ Gore-tex ${ }^{\circledR}$. Auk pess er komið fyrir hring úr gerviefni umhverfis 
míturlokuhringinn til pess að treysta viðgerðina. ${ }^{9}$ Nýleg rannsókn sýndi að einkennalausir sjúklingar með eðlilega starfsemi vinstra slegils sem gangast undir aðgerð vegna mikils míturlokuleka lifa lengur en peir sem einungis eru meðhöndlaðir með lyfjum. ${ }^{18}$ Í annarri rannsókn reyndist langtímalifun einkennalausra sjúklinga sem gengust undir aðgerð mun betri en peirra sem gengust undir aðgerð með einkenni hjartabilunar (NYHA-flokkur III og IV), eða 76\% á móti 53\% lifun eftir 15 ár. ${ }^{19}$ Einnig eru meiri líkur á enduraðgerð og endurteknum leka hjá sjúklingum með einkenni, sérstaklega ef starfsemi vinstri slegils er skert. ${ }^{20}$ Í okkar rannsókn virtust sjúklingar með hrörnunarlokusjúkdóm oft hafa komið frekar seint til aðgerðar, til dæmis var rúmur priðjungur peirra með verulega lækkað útstreymisbrot og tæpur priðjungur með stækkaðan vinstri slegil fyrir aðgerð. Auk pess voru tæpir tveir priðju sjúklinganna með einkenni hjartabilunar fyrir aðgerð. Pessum sjúklingum hefði pví sennilega mátt vísa fyrr til aðgerðar, en yfirleitt er mælt með aðgerð við míturlokuleka áður en marktæk skerðing verður á starfsemi vinstri slegils. ${ }^{6}$

Í starfrænum míturlokuleka gegnir lyfjameðferð stærra hlutverki en skurðaðgerð. Reynd er lyfjameðferð með ACE/AT2-hemlum eða beta-blokkum og stundum spírónólaktón og pvagræsilyf áður en gripið er til skurðaðgerðar. ${ }^{6}$ Ef kransæðasjúkdómur er til staðar er metið hvort kransæðavíkkun eða kransæðahjáveita geti hugsanlega bætt samdrátt hjartans og minnkað lekann. ${ }^{21}$ Hjá sumum einstaklingum með verulega skertan vinstri slegil og vinstra greinrof á hjartariti, getur tveggja-slegla gangráður (biventricular pacemaker) dregið úr starfrænum míturlokuleka. ${ }^{22}$ Ef alvarlegur leki og einkenni hjartabilunar eru til staðar prátt fyrir ofangreinda meðferð er talið rétt að íhuga lokuaðgerð. ${ }^{21}$

Skurðaðgerð vegna starfræns míturlokuleka er hægt að framkvæma með pví að skipta lokunni út eða gera við hana. Líkt og raunin er um aðgerðir við hrörnunarsjúkdómi hefur viðgerðum fjölgað á kostnað lokuskipta. ${ }^{17}$ Viðgerðir við starfrænum leka felast yfirleitt í pví að prengja míturlokuopið með stífum hring. ${ }^{10}$ Aðrar aðferðir, eins og tilfærsla á totuvöðva og lokustög úr gerviefnum (pólítetraflúróetýleni), hafa pó einnig verið próaðar. Í völdum tilvikum kemur til greina að framkvæma svokallaðan Alfieri-saum, en pá er settur saumur frá miðju fremra lokublaði yfir á pað aftara. Petta er pó ekki besta viðgerðin en fljótleg. Á síðustu árum eru aðgerðir með præðingartækni sem byggja á pessari aðferð í örri próun (MitraClip $\left.{ }^{\circledR}\right)^{7}$

Alls var gerð míturlokuviðgerð hjá 55 sjúklingum vegna starfræns míturlokuleka og var lekinn helsta ábending aðgerðar í um priðjungi tilvika. Flestir sjúklinganna (83\%) gengust undir aðra hjartaaðgerð samhliða míturlokuviðgerð og var í mörgum tilvikum einungis um meðal míturlokuleka að ræða. Gagnsemi viðgerðar á meðalmiklum starfrænum leka hefur verið könnuð með framskyggnri rannsókn á sjúklingum sem purftu einnig á kransæðahjáveitu að halda. Í peirri rannsókn var sýnt fram á bætta starfsemi vinstri slegils og minni einkenni hjartabilunar hjá peim sem fengu viðgerð með míturlokuhring og hjáveitu samanborið við pá sem fóru eingöngu í kransæðahjáveitu. ${ }^{23}$ Í okkar rannsókn voru engir sjúklingar með alvarlegan lokuleka vegna blóðpurrðar og líklegast að pessir sjúklingar hafi gengist undir lokuskipti í stað viðgerðar.
Í allt að priðjungi tilfella kemur leki aftur aðeins hálfu ári eftir míturlokuviðgerð. ${ }^{24}$ Prátt fyrir pennan endurtekna leka, sem oftast er vægur, hafa afturskyggnar rannsóknir ótvírætt gefið til kynna að langtímaárangur sé betri við viðgerð en lokuskipti, bæði hvað varðar líkur á enduraðgerð og fylgikvillum tengdum lokunni. ${ }^{25,26}$ Nýleg framskyggn slembirannsókn á sjúklingum með alvarlegan starfrænan míturlokuleka vegna blóðpurrðar í hjartanu bendir pó til pess að lokuskipti geti verið betri valkostur en lokuviðgerð. ${ }^{27}$

Tíðni fylgikvilla var há í pessari rannsókn, en alvarlegir fylgikvillar greindust hjá rúmlega helmingi sjúklinga. Petta er hærra hlutfall en eftir míturlokuskipti hér á landi $(47 \%){ }^{14}$ en einnig ósæðarlokuskipti $(33 \%)^{28}$ og kransæðahjáveituaðgerðir $(9,6 \%){ }^{29}$ Háa tíðni fylgikvilla má að hluta til skýra með pví að $81 \%$ sjúklinganna gengust undir eina eða fleiri hjartaaðgerðir samtímis míturlokuviðgerðinni. Tími á hjarta- og lungnavél og tangartími pessara sjúklinga var pví lengri, sem tengist hærri tíðni fylgikvilla og lengir bæði gjörgæslu- og sjúkrahúsdvöl. Enduraðgerðir vegna blæðingar reyndust tíðar (14\%) og var tíðnin svipuð og eftir míturlokuskipti (15\%). ${ }^{13}$ Hlutfall sjúklinga sem létust innan 30 daga eftir míturlokuviðgerð reyndist hins vegar lægra (6\%) en við míturlokuskipti (9\%). ${ }^{14}$ Petta er í samræmi við erlendar rannsóknir sem sýna betri lifun eftir míturlokuviðgerð borið saman við lokuskipti, sérstaklega hjá sjúklingum með hrörnunarsjúkdóm í lokunni. ${ }^{30}$

Styrkleiki pessarar rannsóknar er að hún nær til heillar pjóðar og voru sjúklingarnir allir meðhöndlaðir á sömu stofnun og eftirfylgd nánast $100 \%$. Á hinn bóginn veikir pað rannsóknina að sjúklingapýðið er tiltölulega lítið og misleitt. Pví er erfitt að bera saman niðurstöður okkar við erlendar rannsóknir með einsleitari sjúklingaefnivið. Rannsóknin er afturskyggn með peim veikleikum sem tilheyra slíkum rannsóknum, til dæmis pegar kemur að samanburði hópa. Skráning er ekki jafn nákvæm í afturskyggnri rannsókn og framskyggnri, til dæmis hvað varðar orsakir á starfrænum míturlokuleka. Einnig voru upplýsingar um langtímafylgd sjúklinga, sérstaklega hvað varðar niðurstöður ómskoðana, ekki nægjanlega ítarlegar. Sennilega hefur hluti sjúklinga aðeins verið ómaður á einkastofum eftir aðgerðina en upplýsingar paðan lágu ekki fyrir í pessari rannsókn, heldur aðeins frá Landspítala og Sjúkrahúsinu á Akureyri. Auk pess nær rannsóknin yfir 12 ára tímabil en á pessum tíma hafa orðið töluverðar framfarir í greiningu og meðferð míturlokuleka.

Míturlokuviðgerðum hefur fjölgað umtalsvert hér á landi á síðasta ártug en míturlokuskiptum hefur fækkað. Árangur míturlokuviðgerða á Íslandi er góður, sérstaklega fyrir sjúklinga með hrörnunarsjúkdóm í lokunni. Fylgikvillar eru algengir eftir aðgerð en dánarhlutfall innan 30 daga er sambærilegt og við margar sambærilegar erlendar rannsóknir.

\section{Pakkir}

Pakkir fær Gunnhildur Jóhannsdóttir skrifstofustjóri á skurðdeild Landspítala fyrir aðstoð við öflun sjúkraskráa. 


\section{Heimildir}

1. Iung B, Vahanian A. Epidemiology of valvular heart disease in the adult. Nat Rev Cardiol 2011; 8: 162-72.

2. Enriquez-Sarano M, Akins CW, Vahanian A. Mitral regurgitation. Lancet 2009; 373: 1382-94.

3. Lancellotti P, Moura L, Pierard LA, Agricola E, Popescu BA, Tribouilloy C, et al. European Association of Echocardiography recommendations for the assessment of valvular regurgitation. Part 2: mitral and tricuspid regurgitation (native valve disease). Eur J Echocardiog 2010; 11: 307-32.

4. Enriquez-Sarano M, Freeman WK, Tribouilloy CM, Orszulak TA, Khandheria BK, Seward JB, et al. Functiona anatomy of mitral regurgitation: accuracy and outcome implications of transesophageal echocardiography. J Am Coll Cardiol 1999; 34: 1129-36.

5. Monin JL, Dehant P, Roiron C, Monchi M, Tabet JY, Clerc $\mathrm{P}$, et al. Functional assessment of mitral regurgitation by transthoracic echocardiography using standardized imaging planes diagnostic accuracy and outcome implications. J Am Coll Cardiol 2005; 46: 302-9.

6. Joint Task Force on the Management of Valvular Heart Disease of the European Society of C, European Association for Cardio-Thoracic S, Vahanian A, Alfieri O, Andreotti F, Antunes MI, et al. Guidelines on the management of valvular heart disease (version 2012). Eur Heart J 2012; 33: 2451-96

7. Feldman T, Foster E, Glower DD, Kar S, Rinaldi M], Fail PS, et al. Percutaneous repair or surgery for mitra regurgitation. N Engl J Med 2011; 364: 1395-406.

8. Carpentier A. Cardiac valve surgery--the „French correction". J Thorac Cardiovasc Surg 1983; 86: 323-37.

9. Adams DH, Rosenhek R, Falk V. Degenerative mitral valve regurgitation: best practice revolution. Eur Heart J 2010; 31: 1958-66.

10. Spoor MT, Geltz A, Bolling SF. Flexible versus nonflexible mitral valve rings for congestive heart failure: differential durability of repair. Circulation 2006; 114(1 Suppl): I67-71.

11. Enriquez-Sarano M, Schaff HV, Orszulak TA, Tajik AJ, Bailey KR, Frye RL. Valve repair improves the outcome of surgery for mitral regurgitation. A multivariate analysis. Circulation 1995; 91: 1022-8.
12. Amirak E, Chan KM, Zakkar M, Punjabi PP. Current status of surgery for degenerative mitral valve disease. Prog Cardiovasc Dis 2009; 51: 454-9.

13. Gillinov AM, Blackstone EH, Nowicki ER, Slisatkorn W, Al-Dossari G, Johnston DR, et al. Valve repair versus valve replacement for degenerative mitral valve disease. J Thorac Cardiovasc Surg 2008; 135: 885-93, 93: e1-2.

14. Ragnarsson S, Sigurdsson MI, Danielsen R, Arnorsson T, Gudbjartsson T. Árangur míturlokuskipta á Íslandi. Læknablaðið 2012; 98: 203-9.

15. Nashef SA, Roques F, Michel P, Gauducheau E, Lemeshow $\mathrm{S}$, Salamon R. European system for cardiac operative risk evaluation (EuroSCORE). Eur J Cardiothorac Surg 1999, 16: 9-13.

16. Nashef SA, Roques F, Sharples LD, Nilsson J, Smith C, Goldstone AR, et al. EuroSCORE II. Eur J Cardiothorac Surg 2012; 41: 734-44; discussion 44-5.

17. Gammie JS, Sheng S, Griffith BP, Peterson ED, Rankin JS, $\mathrm{O}^{\prime}$ Brien $\mathrm{SM}$, et al. Trends in mitral valve surgery in the United States: results from the Society of Thoracic Surgeons Adult Cardiac Surgery Database. Ann Thorac Surg 2009; 87: 1431-7; discussion 7-9.

18. Kang DH, Kim JH, Rim JH, Kim MJ, Yun SC, Song JM, et al. Comparison of early surgery versus conventional treatment in asymptomatic severe mitral regurgitation. Circulation 2009; 119: 797-804.

19. David TE, Ivanov J, Armstrong S, Rakowski H. Late outcomes of mitral valve repair for floppy valves: Implication for asymptomatic patients. J Thorac Cardiovasc Surg 2003; 125: $1143-52$

20. David TE, Armstrong S, McCrindle BW, Manlhiot C. Late outcomes of mitral valve repair for mitral regurgitation due to degenerative disease. Circulation 2013; 127: 148592.

21. Di Salvo TG, Acker MA, Dec GW, Byrne JG. Mitral valve surgery in advanced heart failure. J Am Coll Cardiol 2010; 55: 271-82.

22. Breithardt OA, Sinha AM, Schwammenthal E, Bidaoui N, Markus KU, Franke A, et al. Acute effects of cardiac resynchronization therapy on functional mitral regurgitation in advanced systolic heart failure. J Am Coll Cardiol 2003: 41: 765-70.
23. Fattouch K, Guccione F, Sampognaro R, Panzarella G, Corrado E, Navarra E, et al. POINT: Efficacy of adding mitral valve restrictive annuloplasty to coronary artery bypass grafting in patients with moderate ischemic mitral valve regurgitation: a randomized trial. J Thorac Cardiovasc Surg 2009; 138: 278-85.

24. McGee EC, Gillinov AM, Blackstone EH, Rajeswaran J, Cohen G, Najam F, et al. Recurrent mitral regurgitation after annuloplasty for functional ischemic mitral regurgitation. J Thorac Cardiovasc Surg 2004; 128: 916-24.

25. Gillinov AM, Wierup PN, Blackstone EH, Bishay ES, Cosgrove DM, White $\mathrm{J}$, et al. Is repair preferable to replacement for ischemic mitral regurgitation? J Thorac Cardiovasc Surg 2001; 122: 1125-41.

26. Lorusso R, Gelsomino S, Vizzardi E, D’Aloia A, De Cicco G, Luca F, et al. Mitral valve repair or replacement for ischemic mitral regurgitation? The Italian Study on the Treatment of Ischemic Mitral Regurgitation (ISTIMIR). J Thorac Cardiovasc Surg 2013; 145: 128-39; discussion 37-8.

27. Acker MA, Parides MK, Perrault LP, Moskowitz AJ Gelijns AC, Voisine P, et al. Mitral-Valve Repair versus Replacement for Severe Ischemic Mitral Regurgitation. N Eng J Med 2014; 370: 23-32.

28. Ingvarsdottir IL, Viktorsson SA, Hreinsson K, Sigurdsson MI, Helgadottir S, Arnorsson P, et al. Lokuskipti vegna ósæðarlokuprengsla á Íslandi 2002-2006: ábendingar og snemmkomnir fylgikvillar. Læknablaðið 2011; 97: 523-7.

29. Oddsson SJ, Sigurionsson $H$, Helgadottir $S$, Sigurdsson MI, Viktorsson SA, Arnorsson T, et al. Tengsl offitu við árangur kransæðahjáveituaðgerða. Læknablaðið 2011; 97: 223-8.

30. Mohty D, Orszulak TA, Schaff HV, Avierinos JF, Tajik JA, Enriquez-Sarano M. Very long-term survival and durability of mitral valve repair for mitral valve prolapse. Circulation 2001; 104 (12 Suppl 1): I1-I7.

\section{ENGLISH SUMMARY}

\section{Surgical outcome of mitral valve repair in Iceland 2001-2012}

Johanna Frida Gudmundsdottir ${ }^{1}$, Sigurdur Ragnarsson ${ }^{3}$, Arnar Geirsson¹, Ragnar Danielsen² , Tomas Gudbjartsson ${ }^{1,4}$

Objectives: To review, for the first time, the outcome of mitral valve repair operations in Iceland.

Material and methods: A retrospective study of all mitral valve repair patients (average age 64 yrs, 74\% males) operated in Iceland 2001-2012. All 125 patients had mitral regurgitation; either due to degenerative disease (56\%) or functional regurgitation (44\%). Survival was estimated using the Kaplan-Meier method. The median follow-up time was 3.9 years

Results: The number repair-procedures increased from 39 during the first half of the study period to 86 during the latter period. The mean EuroSCORE was $12.9 \%$ and $2 / 3$ of the patients were in NYHA class III/IV. Half of them had severe mitral regurgitation, $12 \%$ had a recent myocardial infarction, and $10 \%$ a history of previous cardiac surgery. A ring annuloplasty was performed in $98 \%$ of cases, a posterior leaflet resection was done in 51 patients (41\%), 28 received artificial chordae $\left(\right.$ Goretex ${ }^{\circledR}$ ) and 7 an Alfieri-stitch. Concomitant cardiac surgery was performed in $83 \%$ of cases, where coronary artery bypass $(53 \%)$, Mazeprocedure (31\%) or aortic valve replacement (19\%) were most common. Major complications occurred in $56 \%$ of the cases and minor complications were noted in $71 \%$ of cases. Two patients later required mitral valve replacement. Eight patients died within 30 days $(6 \%)$ and 5 -year overall survival was $79 \%$; or $84 \%$ and $74 \%$ for the degenerative and functional groups, respectively.

Conclusions: The number of mitral valve repairs in Iceland increased significantly over the study period. Complications are common but operative mortality and long-term survival is similar to that reported in studies from other countries. 